\title{
Identification of genes related to carcinogenesis of oral leukoplakia by oligo cancer microarray analysis
}

\author{
WEIWEI LIU ${ }^{1}$, WENLING ZHENG $^{1}$, JUN XIE $^{2}$, BAO ZHANG $^{1}$, WENLI MA $^{1}$ and XIANJIU CHEN ${ }^{2}$ \\ ${ }^{1}$ The Institute of Genetic Engineering, Southern Medical University, Guangzhou 510515; ${ }^{2}$ Biochemistry and \\ Molecular Department, Shanxi Medical University, No. 56 Xinjian South Road, Taiyuan 030001, P.R. China
}

Received December 15, 2010; Accepted February 14, 2011

DOI: 10.3892/or.2011.1281

\begin{abstract}
The aim of this study was to identify genes that are predictive of carcinogenic change in patients of oral leukoplakia (OLK) using a cancer-related microarray. Candidate biomarkers were discovered using the Oligo GEArray OHS-802 and validated on independent samples by semi-quantitative reverse transcription-PCR (RT-PCR) and real-time RT-PCR. Both the discovery and the validation cohorts of samples included normal oral tissues, OLK tissues and oral squamous cell carcinoma (OSCC) tissues. Based on the microarray results, we found that there were nine genes successively up-regulated or down-regulated more than 2-fold between the normal group and OLK group and then again between the OLK group and OSCC group. The expression levels of the nine signature genes had statistically significant differences $(\mathrm{p}<0.05)$ between the OLK and normal groups and between the OSCC and OLK groups. In summary, the expression of the 9 signature genes might be representative of OLK carcinogenesis. A cancer-related microarray was used to identify a panel of candidate biomarkers for determining carcinogenesis of OLK lesions, in combination with semi-quantitative and real-time RT-PCR to validate the results. Our data indicated that alterations in gene expression that result in carcinogenesis can be identified in precancerous oral tissues.
\end{abstract}

\section{Introduction}

The American Cancer Society estimates that in 2010 there will be 36,540 new cases of oral and pharyngeal cancers and

Correspondence to: Dr Wenli Ma, The Institute of Genetic Engineering, Southern Medical University, Guangzhou 510515, P.R. China

E-mail:wenlima8@gmail.com

Dr Xianjiu Chen, Biochemistry and Molecular Department, Shanxi Medical University, No. 56 Xinjian South Road, Taiyuan 030001, P.R. China

E-mail: xianj.chen@gmail.com

Key words: microarray, oral leukoplakia, carcinogenesis, oral squamous cell carcinoma, signature genes, homosapiens
7,880 deaths attributed to them in the USA (1). Worldwide, the problem is much greater, with over 350,000-400,000 new cases being diagnosed each year (2). Notably, incidence in young adults $(<40$ years) is increasing in the USA $(3,4)$ and worldwide $(5,6)$. Of the cancers occurring in the region of the mouth and pharynx, the vast majority are restricted to the oral cavity. Approximately 90 percent of oral cancers are squamous cell carcinomas (5). Sixty percent of oral carcinomas are at an advanced stage by the time they are detected (7). Despite therapeutic and diagnostic advances, the 5-year survival rate for oral squamous cell carcinoma (OSCC) remains at about $50 \%(8-10)$.

Oral leukoplakia (OLK), the best-known premalignant oral lesion, is defined by the World Health Organization as 'a white patch or plaque that can not be characterized clinically or pathologically as any other disease' (11). Nowadays, the standard treatment for OLK patients remains surgical excision. Unfortunately, while the majority of OLK patients will be cured by surgery, $1.58-27.27 \%$ of the patients will still experience carcinogenic changes (12).

Significant problems encountered in the clinical management of OLK patients include the inability to determine on time, whether and when carcinogenesis will occur and accurately predict which patients are at greater risk of developing OSCC following surgery. Once OSCC develops, it is recommended that patients undergo another surgical excision. By this time, the surgery might affect their ability to chew, swallow, or talk, and disrupt their general outlook. Furthermore, the patients have to endure the consequences of possible metastases following the surgery. Typically, the earlier the cancer is detected and diagnosed, the more likely it is for the treatment to be successful, and the better the quality of life for all oral cancer patients. Thus far, detection of OSCC has been based mainly on expert clinical examination and histological analysis of suspicious areas. However, these are only surrogate measures of the true underlying molecular alterations that are associated with carcinogenesis. Therefore, sensitive and specific biomarkers for OSCC may be helpful in screening high-risk OLK patients. Attempts to find biomarkers that identify premalignant OSCC and cancerous lesions have resulted in several candidate genes associated with OSCC tumor progression including P53, cyclin D1, epidermal growth factor receptor $(13,14)$, AgNOR (15), and Ki-67 
(16). However, to date there are no widely accepted molecular biomarkers for OLK carcinogenesis.

In recent years, modern high-throughput genomic approaches have emerged as a means of rapidly identifying candidate genes that are associated with carcinogenesis, including those for OLK (17-19). However, the concordance among different studies on marker genes of carcinogenesis of OLK is low. Data inconsistency can be particularly explained by the use of different microarray technologies and different patients' demographics. Thus, it is difficult to make a direct comparison with our results.

Thus, the goal of this study was to identify a gene expression signature for OLK carcinogenesis. By analyzing microarray data from normal oral tissue, OLK tissue, and OSCC tissue and by validation at the RNA level using several independent validation samples, we identified a panel of candidate biomarkers that can predict carcinogenesis of OLK. This is only the initial step towards developing a detection system for OLK carcinogenesis.

\section{Materials and methods}

Tissue specimens. Consent was obtained from all patients that participated in this study in accordance with guidelines set forth by the Institutional Review Board at Southern Medical University and Shanxi Medical University. Adult patients with clinically measurable oral leukoplakia (OLK) were eligible for enrollment in the study. All tumor samples were obtained from surgical resection specimens from patients undergoing surgery for OSCC using standardized procedures. In this study, cancers of the oral cavity included squamous cell carcinomas of the tongue, floor of the mouth, buccal mucosa, lips, hard and soft palate, and gingiva. After resection, tissues were fresh-frozen in liquid nitrogen. Samples were banked at $-80^{\circ} \mathrm{C}$ for storage until later use. All normal samples were obtained from surgical resection specimens from patients who either had surgical tooth extractions or had non-epithelial-related pathology, and were typically 2-3 cm, with no grossly appreciable tumor, leukoplakia, or erythroplakia detected. Touch preparation analysis was used to confirm that each normal-appearing mucosa did not contain carcinogenic cells.

All sections were evaluated cytologically and diagnoses were confirmed. All tissue sections were fixed and stained with $H \& E$ and evaluated by two experienced pathologists and histological analyses were done to ensure that each specimen was pure for microarray analysis. Those samples that did not meet these criteria were rejected for this study.

The functional gene groupings of the human cancer microarray. Microarray analysis was performed using the Oligo GEArray ${ }^{\circledR}$ Human Cancer Microarray, containing 440 genes (SuperArray, Cat. No. OHS-802, USA). An individual gene may exist in more than one functional group, and show different functions in tumor progression. Taken in this sense, the genechip covered 704 genes (Table I). The genes represented by this array include but are not limited to tumor suppressors, oncogenes, signal transduction molecules, growth factors, growth factor receptors, and angiogenesis factors.
Table I. The functional distribution of Oligo Cancer Microarray (SuperArray, USA).

Functional gene grouping

Gene scalar

Apoptosis 76

Cell cycle 127

Cell growth and differentiation 167

Cell motility

Signal transduction

118

Other cancer-related genes

188

Total

704

The major functional gene groupings on the OHS-802 Oligo GEArray for human cancer. An individual gene may exist in more than one functional group, and show different functions in tumor progression. In all, the genechip covered 704 genes.

RNA preparation and microarray analysis. For RNA isolation, each tissue specimen was placed in a liquid nitrogen-chilled mortar and the tissue ground to a fine powder. The liquid nitrogen was evaporated, and the tissue was homogenized in TRIzol (Invitrogen, Carlsbad, CA). Total RNA was isolated using the TRIzol method and dissolved in RNase-free water. High-quality RNA was obtained as suggested by the wellpreserved 28S and 18S ribosomal RNA bands (present in an approximately 2:1 intensity ratio), along with A260/A280 ratios between 1.8 and 2.0. Quality and integrity of total RNA was tested with a Bioanalyzer 2100 (Agilent Technologies Inc., Palo Alto, CA, USA).

Total RNA samples were submitted to KangChen Bio-tech for microarray analysis using Oligo GEArray OHS-802 (SuperArray, Frederick, USA). Samples were run on an Agilent Bioanalyzer to confirm integrity and concentration. For target preparation and hybridization, all protocols were conducted as described in the manufacturer's instructions. Briefly, for cRNA labeling and synthesis, TrueLabeling-AMP ${ }^{\text {тм }}$ Linear RNA Amplification Kit (SuperArray), SuperArray ArrayGrade cRNA Cleanup Kit (SuperArray Cat. No. GA-012), Biotin-16dUTP (Roche Cat. No. 1-093-070) were used in accordance with the manufacturer's instructions. The Oligo GEArray was pre-hybridized with GEAhyb Hybridization Solution (SuperArray Bioscience) in a disposable hybridization tube. Then $10 \mu \mathrm{g}$ of biotin-labeled cRNA target prepared using the TrueLabeling-AMP kit was added to $0.75 \mathrm{ml}$ of pre-warmed GEAhyb Hybridization Solution. The solution was mixed well, and the Target Hybridization Mix was kept at $60^{\circ} \mathrm{C}$. The pre-hybridization solution was discarded from the hybridization tube. The Target Hybridization Mix containing the labeled cRNA target was added to the tube. It was hybridized overnight at $60^{\circ} \mathrm{C}$ with continuous agitation at 5-10 rpm. The microarrays were washed at low (2X SSC, 1\% SDS: Mix $10 \mathrm{ml} 20 \mathrm{X}$ SSC, $5 \mathrm{ml} \mathrm{20 \%} \mathrm{SDS,} \mathrm{and} 85 \mathrm{ml}$ $\left.\mathrm{ddH}_{2} \mathrm{O}\right)$ and high (0.1X SSC, 0.5\% SDS: Mix $0.5 \mathrm{ml} \mathrm{20X}$ SSC, $2.5 \mathrm{ml} 20 \% \mathrm{SDS}$, and $\left.97 \mathrm{ml} \mathrm{ddH}_{2} \mathrm{O}\right)$ stringency. Then a Chemiluminescent Detection Kit (SuperArray Bioscience, Cat. No. D-01) was used to detect chemiluminescent grayscale, according to the manufacturer's instructions. After 
Table II. Primers used for relative RT-PCR amplification.

\begin{tabular}{|c|c|c|c|c|}
\hline Genes & Description & $\begin{array}{l}\text { GeneBank } \\
\text { No. }\end{array}$ & Primers $\left(5^{\prime}-3^{\prime}\right)$ & $\begin{array}{l}\text { Product size } \\
\quad(\mathrm{bp})\end{array}$ \\
\hline NF-1 & Neurofibromin & NM_000267 & $\begin{array}{l}\text { F: GTCATTGCCTTCCGTTCC } \\
\text { R: CACCCAAAGACAACAAGAGC }\end{array}$ & 239 \\
\hline ACP-2 & Acid phosphatase-2 & NM_001610 & $\begin{array}{l}\text { F: AACCAAGGAGGGGATGCT } \\
\text { R: AGGAATAGGCTGCCACGA }\end{array}$ & 217 \\
\hline BCL-2 & B-cell leukemia/lymphoma-2 & NM_000633 & $\begin{array}{l}\text { F: TGGGATCGTTGCCTTATG } \\
\text { R: GCTATTTTATTGGATGTGCTTT }\end{array}$ & 275 \\
\hline CLK-3 & CDC-like kinase 3 & NM_001292 & $\begin{array}{l}\text { F: GTGGTGGAGTGCTTGGAC } \\
\text { R: CTAAGGGCGTGGCAGA }\end{array}$ & 308 \\
\hline FKBP-8 & FK506 binding protein $8,38 \mathrm{kDa}$ & NM_012181 & $\begin{array}{l}\text { F: CTCCTACGACCTCGCCATCA } \\
\text { R: CCCAAACAGCCACTTCCAT }\end{array}$ & 454 \\
\hline SOCS-3 & Suppressor of cytokine signaling 3 & NM_003955 & $\begin{array}{l}\text { F: CCCCAGAAGAGCCTATTACATC } \\
\text { R: AGGAACTCCCGAATGGGCCCCGGCA }\end{array}$ & 179 \\
\hline XRCC-1 & $\begin{array}{l}\text { X-ray repair complementing } \\
\text { defective repair in Chinese } \\
\text { hamster cells }\end{array}$ & NM_006297 & $\begin{array}{l}\text { F: GCTTGAGTTTTGTACGGTTTC } \\
\text { R: ACTGGGGATGTCTTGTTGAT }\end{array}$ & 175 \\
\hline CTNNB-1 & Cadherin-associated protein $\beta 1$ & NM_001904 & $\begin{array}{l}\text { F: CCAAGTGGGTGGTATAGAG } \\
\text { R: GGGACAAAGGGCAAGA }\end{array}$ & 247 \\
\hline GDF-15 & $\begin{array}{l}\text { Growth and differentiation } \\
\text { factor } 15\end{array}$ & NM_004864 & $\begin{array}{l}\text { F: CGCTCCAGACCTATGATGACTT } \\
\text { R: CCTTGAGCCCATTCCACA }\end{array}$ & 128 \\
\hline$\beta$-actin & $\beta$-actin & NM_001101.2 & $\begin{array}{l}\text { F: AGCGCAAGTACTCCGTGTG } \\
\text { R: AAGCAATGCTATCACCTCC }\end{array}$ & 501 \\
\hline GAPDH & $\begin{array}{l}\text { Glyceraldehye-3-phosphate } \\
\text { dehydrogenase }\end{array}$ & NM_002046.3 & $\begin{array}{l}\text { F: GAAGGTCGGAGTCAACGG } \\
\text { R: GGAAGATGGTGATGGGATT }\end{array}$ & 221 \\
\hline
\end{tabular}

Table III. The conditions for reverse transcription for the genes studied.

\begin{tabular}{lrrr}
\hline Step no. & Temperature $\left({ }^{\circ} \mathrm{C}\right)$ & Time $(\min )$ & Cycles \\
\hline 1 & 42 & 30 & \\
2 & 99 & 5 & 1 \\
3 & 5 & 5 &
\end{tabular}

the CDP-Star incubation, the GEArray was ready for image acquisition. The chemiluminescent array image was captured using X-ray film and a flatbed desktop scanner. All images were saved as electronic files in grayscale ( 8 or 16 bit). The web-based completely integrated GEArray Expression Analysis Suite was used to complete the data analysis. To ensure the reliability of the data, genes were considered to be differentially expressed if the P-values were $<0.05$ (Student's t-test), and had a fold change $>2.0$.

Semi-quantitative reverse transcription-PCR (RT-PCR). RT-PCR was performed to validate the microarray analysis, using RNA extracts from several OSCC, leukoplakia and normal samples. RNA extraction was performed as previously described. Then 9 genes were selected (CLK-3, CTNNB-1, GDF-15, FKBP-8, SOCS-3, NF-1, BCL-2, XRCC-1 and ACP-2) based on the genechip results (genes showing 2-fold or higher difference in expression as compared to other groups on the genechips were defined as positive genes) and each PCR primer pair was designed (Table II) using the Primer Premier 5 software (Premier Biosoft International, USA). PrimeScript $^{\mathrm{TM}}$ RT-PCR Kit (two steps RT-PCR Kit, Takara, Japan) was used for gene amplification. All gene-specific primers used for RT-PCR were purchased from Takara. Each reaction was carried out in a PTC-100 PCR machine (MJRearch, USA). The reaction conditions were showed as Tables III and IV. After PCR amplification, an aliquot of the PCR product was separated on agarose gel and stained with Goldviewna I. The density of the stained bands was analyzed by Kodak Digital Science 1D Image Analysis Software. The results were normalized as a ratio of each specific mRNA signal to the glyceraldehyde-3-phosphate dehydrogenase and $\beta$-actin gene signal within the same RNA sample. cDNA obtained from normal oral epithelium was used as a negative control. We confirmed reproducibility by processing all samples at least twice.

Quantitative real-time PCR. Changes in mRNA levels were further compared and validated by quantitative real-time 
Table IV. The conditions for polymerase chain reaction for genes studied.

\begin{tabular}{lccccc}
\hline Genes & $\begin{array}{c}\text { Annealing temperature } \\
\left({ }^{\circ} \mathrm{C}\right)\end{array}$ & $\begin{array}{c}\text { Annealing time } \\
(\mathrm{sec})\end{array}$ & $\begin{array}{c}\text { Extension temperature } \\
\left({ }^{\circ} \mathrm{C}\right)\end{array}$ & $\begin{array}{c}\text { Extension time } \\
(\mathrm{min})\end{array}$ & Cycles \\
\hline NF-1 & 53 & 45 & 72 & 1 & 50 \\
ACP-2 & 55 & 30 & 72 & 1 & 35 \\
BCL-2 & 53 & 30 & 72 & 1 & 35 \\
CLK-3 & 53 & 45 & 72 & 1 & 50 \\
FKBP-8 & 51 & 30 & 72 & 1 & 35 \\
SOCS-3 & 55 & 30 & 72 & 1 & 50 \\
XRCC-1 & 53 & 30 & 72 & 1 & 35 \\
CTNNB-1 & 52 & 30 & 72 & 1 & 40 \\
GDF-15 & 55 & 30 & & & 35 \\
\hline
\end{tabular}

Table V. Primers and PCR conditions for GDF-15, SOCS-3, XRCC-1 and the internal control $\beta$-actin.

\begin{tabular}{lllc}
\hline Genes & \multicolumn{1}{c}{ Primers } & Annealing temperature $\left({ }^{\circ} \mathrm{C}\right)$ & Product length $(\mathrm{bp})$ \\
\hline$\beta$-actin & F: 5'-CCTGTACGCCAACACAGTGC-3' & 59 & 211 \\
& R: 5'-ATACTCCTGCTTGCTGATCC-3' & & 115 \\
GDF-15 & F: 5'-TGACTTGTTAGCCAAAGACTGCC-3' & 59 & 113 \\
& R: 5'-GAACCTTGAGCCCATTCCACA-3' & 59 & 248 \\
SOCS-3 & F: 5'-TCCTGGTGGGACGATAGCA-3' & & \\
& R: 5'-CCCTGGCAGTTCTCATTAGTTCA-3' & 60 & 2 \\
\hline
\end{tabular}

RT-PCR analysis. Three genes were randomly chosen from the positive genes detected based on the microarray data and RT-PCR results: growth and differentiation factor 15 (GDF-15, NM_004864), X-ray repair complementing defective repair in Chinese hamster cells (XRCC-1, NM_006297), suppressor of cytokine signaling 3 (SOCS-3, NM_003955). $\beta$-actin was used as the internal control for normalization. The Rotor-Gene 3000 real-time PCR machine (Corbett Research, Australia) was used.

Quantitative real-time PCR was performed in the presence of SYBR-Green (Molecular Probes, USA). Comparison with housekeeping gene allowed relative quantification of monitored genes in different cDNA samples. Briefly, $2 \mu \mathrm{g}$ of mRNA were converted to cDNA in a total volume of $20 \mu 1$. One microliter of this mixture was used as template in a final reaction volume of $25 \mu \mathrm{l}$ for PCR amplification. All genespecific primers used for real-time PCR were purchased from Takara. The primer sequences of three genes and $\beta$-actin are shown in Table V. The PCR reaction conditions for each gene were as follows: $\beta$-actin, $95^{\circ} \mathrm{C}, 5 \mathrm{~min} ; 30$ cycles $\left(95^{\circ} \mathrm{C}, 10 \mathrm{sec}\right.$; $\left.59^{\circ} \mathrm{C}, 15 \mathrm{sec} ; 72^{\circ} \mathrm{C}, 20 \mathrm{sec} ; 84^{\circ} \mathrm{C}, 5 \mathrm{sec}\right) ; \mathrm{GDF} 15,95^{\circ} \mathrm{C}, 5 \mathrm{~min}$; 35 cycles $\left(95^{\circ} \mathrm{C}, 10 \mathrm{sec} ; 59^{\circ} \mathrm{C}, 15 \mathrm{sec} ; 72^{\circ} \mathrm{C}, 20 \mathrm{sec} ; 82.5^{\circ} \mathrm{C}, 5\right.$ sec); SOCS3, $95^{\circ} \mathrm{C}, 5 \mathrm{~min} ; 35$ cycles $\left(95^{\circ} \mathrm{C}, 10 \mathrm{sec} ; 59^{\circ} \mathrm{C}, 15\right.$ sec; $\left.72^{\circ} \mathrm{C}, 20 \mathrm{sec} ; 82.5^{\circ} \mathrm{C}, 5 \mathrm{sec}\right) ; \mathrm{XRCC} 1 ; 95^{\circ} \mathrm{C}, 5 \mathrm{~min} ; 35$ cycles $\left(95^{\circ} \mathrm{C}, 10 \mathrm{sec} ; 60^{\circ} \mathrm{C}, 15 \mathrm{sec} ; 72^{\circ} \mathrm{C}, 20 \mathrm{sec} ; 84.5^{\circ} \mathrm{C}, 5 \mathrm{sec}\right)$.

Cumulative fluorescence was measured at the end of the extension phase of each cycle. Product-specific amplification was confirmed by a melting curve analysis and agarose gel electrophoresis analysis. Quantification was done at the log-linear phase of the reaction and cycle numbers obtained at this point were plotted against a standard curve prepared with serially diluted samples.

Statistical analysis. Initial data analysis was done using the web-based completely integrated GEArray Expression Analysis Suite to quantitate expression levels for targeted genes. This signal value, a relative measure of the expression level, was computed for each assayed gene. After exclusion of the highest and lowest $2 \%$, the average total chip signal was calculated. All PCR reactions were carried out thrice for calculation of SD. The t-test was performed using the SPSS 11.5 software to calculate for the statistical significance. P-values $<0.05$ were considered statistically significant.

\section{Results}

Determination of genes related to oral leukoplakia carcinogenesis. Gene expression profiling was performed using Oligo GEArray OHS-802 on three OLK tissues, three OSCC tissues, and three normal oral tissues as control group. After the normalization of the initial results, gene expression level (grayscale) of the genechips for the three groups showed differences between one another. According to the normalized grayscale 
Table VI. Genes found to have been related to the process of carcinogenesis of OSCC.

\begin{tabular}{|c|c|c|c|c|c|c|c|}
\hline \multirow[b]{2}{*}{ Regulating mode } & \multirow[b]{2}{*}{ GeneBank } & \multirow[b]{2}{*}{ Positive genes } & \multicolumn{3}{|c|}{ Tissue } & \multicolumn{2}{|c|}{ Expression variation } \\
\hline & & & Normal (1) & OLK (2) & OSCC (3) & $(1) \rightarrow(2)$ & $(2) \rightarrow(3)$ \\
\hline \multicolumn{8}{|l|}{ Down-regulated } \\
\hline & NM_001610 & ACP-2 & $0.2097 \pm 0.0210$ & $0.0496 \pm 0.0050$ & $0.0034 \pm 0.0004$ & 2.72 & 3.44 \\
\hline & NM_000633 & BCL-2 & $0.0227 \pm 0.0023$ & $0.0084 \pm 0.0009$ & $0.0022 \pm 0.0002$ & 4.23 & 13.23 \\
\hline & NM_003955 & SOCS-3 & $0.1335 \pm 0.0134$ & $0.0254 \pm 0.0026$ & $0.0058 \pm 0.0006$ & 5.25 & 3.95 \\
\hline \multicolumn{8}{|l|}{ Up-regulated } \\
\hline & NM_001292 & CLK-3 & $0.0070 \pm 0.0008$ & $0.0254 \pm 0.0026$ & $0.0708 \pm 0.0075$ & 3.60 & 3.09 \\
\hline & NM_001904 & CTNNB-1 & $0.0077 \pm 0.0008$ & $0.0189 \pm 0.0019$ & $0.0782 \pm 0.0083$ & 2.46 & 4.59 \\
\hline & NM_012181 & FKBP-8 & $0.0014 \pm 0.0002$ & $0.0080 \pm 0.0008$ & $0.0261 \pm 0.0028$ & 5.63 & 3.59 \\
\hline & NM_004864 & GDF-15 & $0.0047 \pm 0.0005$ & $0.0188 \pm 0.0019$ & $0.1067 \pm 0.0112$ & 4.00 & 6.29 \\
\hline & NM_000267 & NF-1 & $0.0006 \pm 0.0001$ & $0.0077 \pm 0.0008$ & $0.0463 \pm 0.0049$ & 11.97 & 6.66 \\
\hline & NM_006297 & XRCC-1 & $0.0086 \pm 0.0009$ & $0.0411 \pm 0.0041$ & $0.0967 \pm 0.0102$ & 4.77 & 2.60 \\
\hline
\end{tabular}

ACP-2, BCL-2, and SOCS-3 were successively down-regulated $>2$-fold in transition between normal tissue, OLK, and OSCC tissue, while the other 6 genes were up-regulated $>2$-fold.

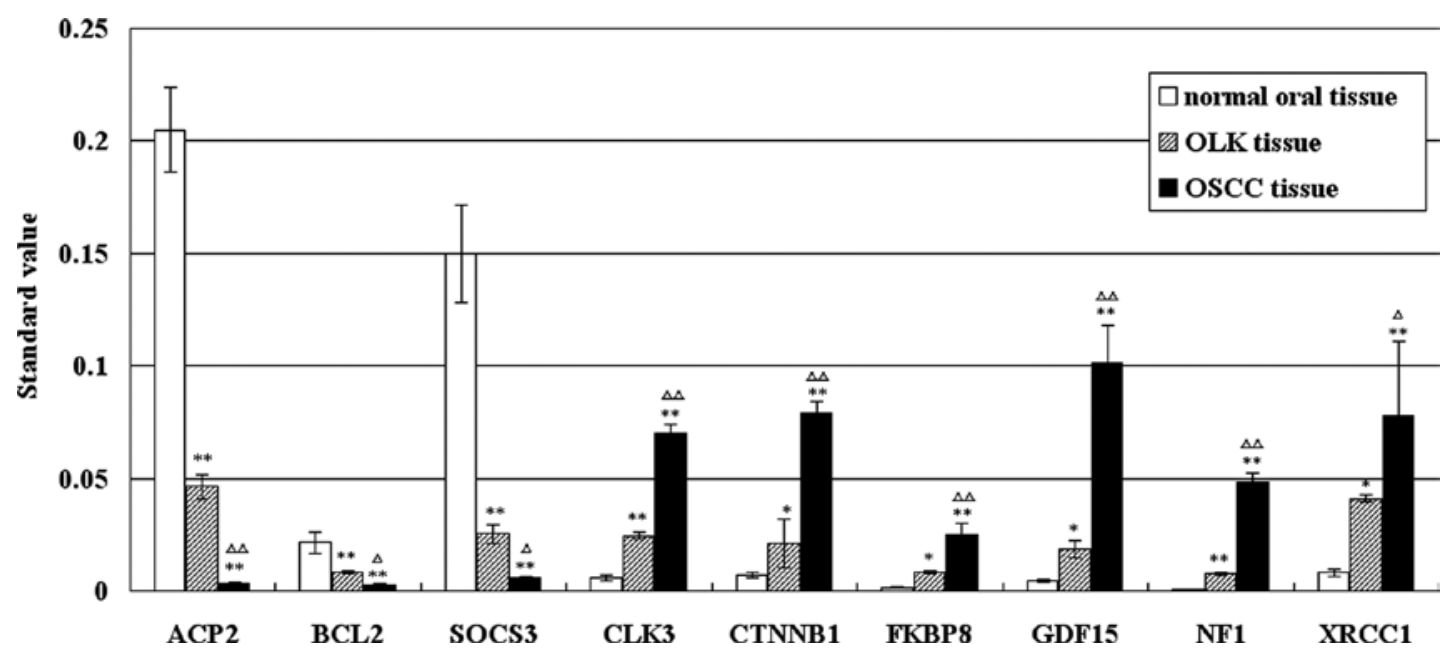

Figure 1. An illustration of genechip results of 9 signal genes in the 3 kinds of oral mucosa (normal oral tissue-white, OLK tissue-grey, OSCC tissue-black), Demonstrated is a successive down-regulation in the expression of ACP-2, BLC-2 and SOCS-3, and up-regulation of all the other 6 genes studied, while in transition between normal, OLK and OSCC tissue. Compared with normal tissue ${ }^{*} \mathrm{P}<0.05,{ }^{* *} \mathrm{P}<0.01$; compared with OLK tissue ${ }^{\triangle} \mathrm{P}<0.05,{ }^{\triangle} \triangle \mathrm{P}<0.01$.

of each gene, comparisons between groups were performed. Genes were considered to be positive when the grayscale ratio for the gene between each two groups was 2-fold or greater (data not shown). Among these positive genes, from the normal, OLK and OSCC groups, if the ratio for a certain gene successively up-regulated or down-regulated $>2$-fold, it was regarded a signature gene for oral epithelial carcinogenesis. We found there were only nine signature genes that met these criteria (Table VI), which suggested that these overexpressed or underexpressed genes might be the driver genes for the carcinogenic process (Fig. 1).

Validation of the signature genes by RT-PCR. After the microarray detection, we used RT-PCR to validate the microarray results and ensure ACP-2 and the other eight genes were eligible signature genes to measure the level of carcinogenesis of the oral mucosa. The RT-PCR results of the nine signature genes are shown in Fig. 2. We then used the Kodak Gel Image Analysis System to quantify the grayscale of each gene (Fig. 3). After this, we compared the results obtained from the microarray and RT-PCR. The results (Table VII) showed that the expression level of the nine signature genes had statistically significant differences $(p<0.05)$ between OLK group and normal group and between OSCC group and OLK group. Based on the above-mentioned results, we can conclude that the microarray result was reliable.

ACP-2, BCL-2 and SOCS-3 were down-regulated in the transition from normal to OLK and OLK to OSCC tissue successively. On the other hand, the rest of the genes listed 


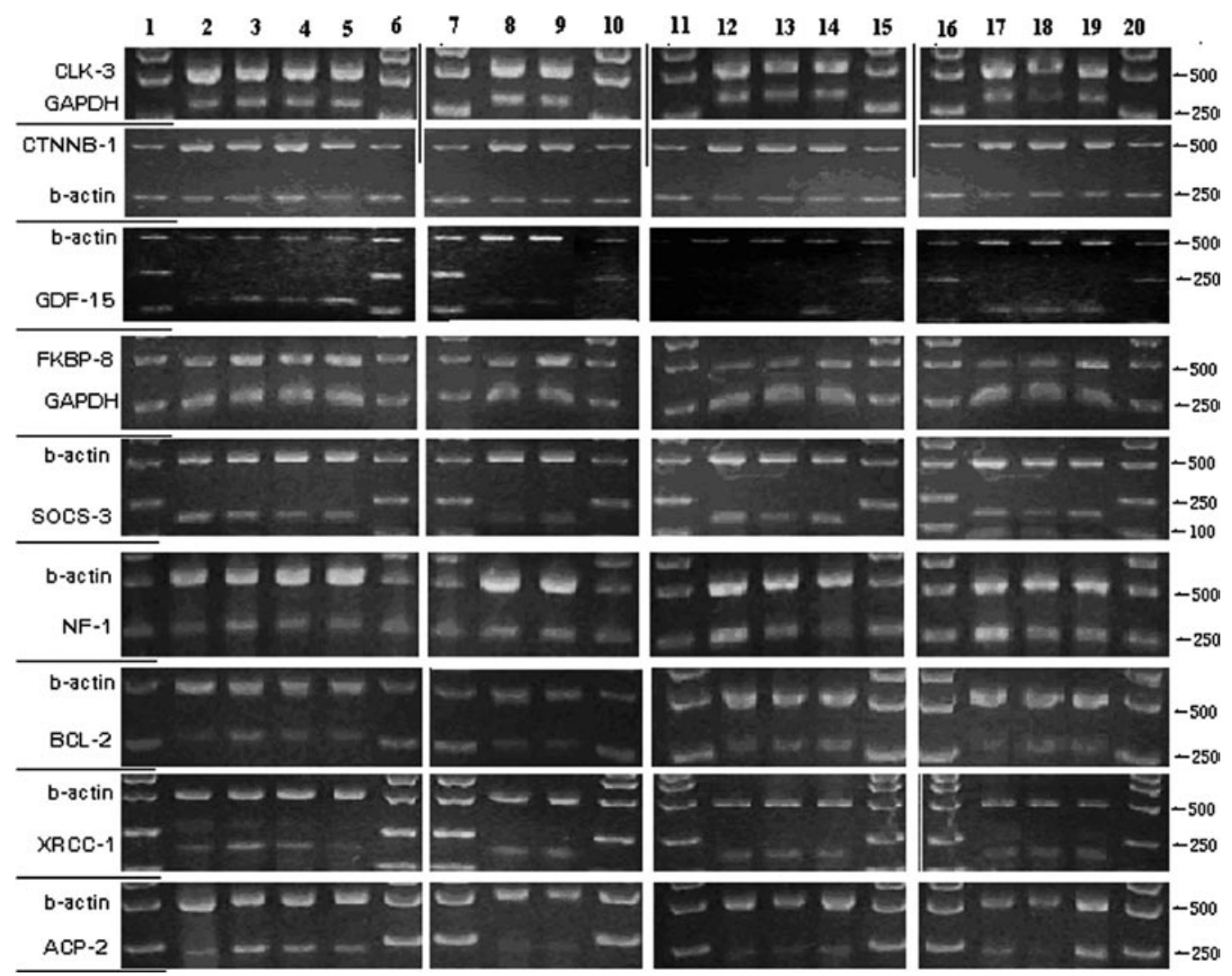

Figure 2. The RT-PCR results of 9 signal genes in the 3 kinds of oral mucosa (normal, OLK and OSCC tissue). Rows 1, 6, 7, 10, 11, 15, 16 and 20 are DNA molecular markers; rows 2, 3, 4, 5, 14, 19 represent OSCC tissues; rows 8, 9, 13, 18 represent OLK tissue; rows 12 and 17 represent normal oral tissue. $\beta$-actin and GAPDH were used as internal controls.

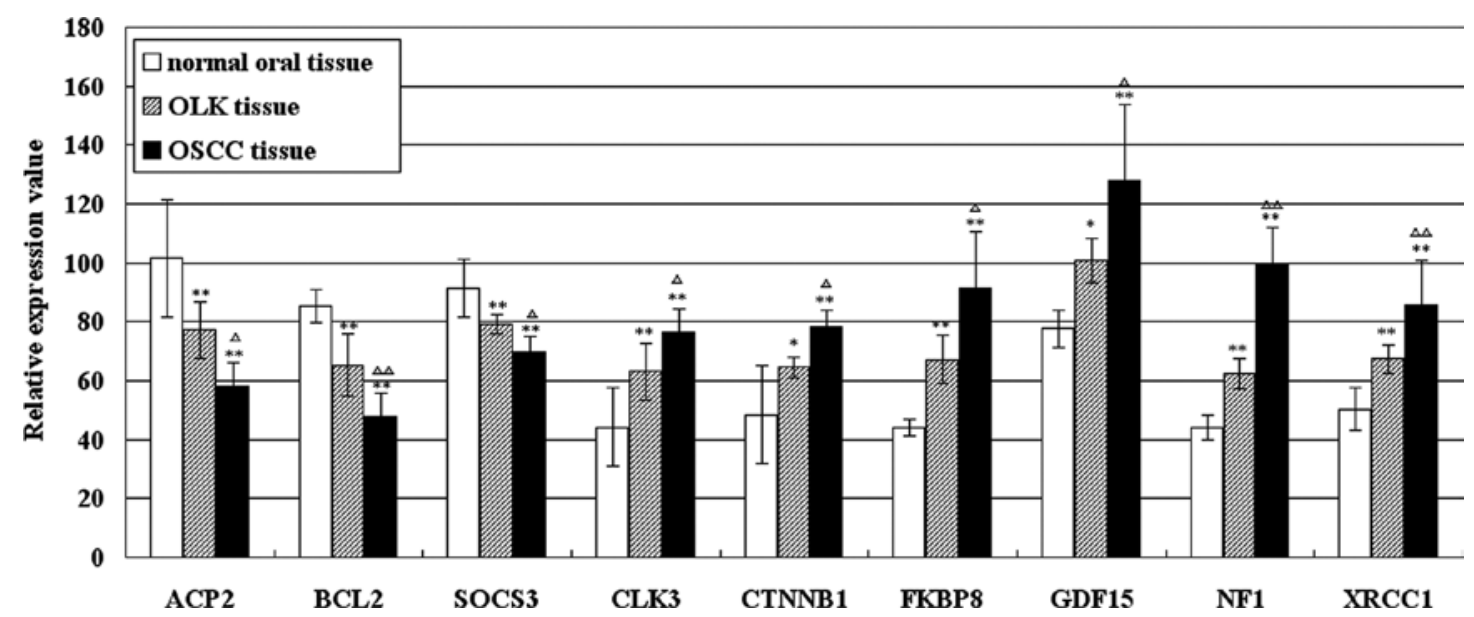

Figure 3. An illustration of RT-PCR results of 9 signal genes in the 3 kinds of oral mucosa (normal oral tissue, white; OLK tissue, grey; OSCC tissue, black). Demonstrated is a successive down-regulation in the expression of ACP-2, BLC-2 and SOCS-3, and up-regulation of all the other 6 genes studied, while in transition between normal, OLK and OSCC tissue. Compared with normal tissue ${ }^{*} \mathrm{P}<0.05,{ }^{* *} \mathrm{P}<0.01$; compared with $\mathrm{OLK}$ tissue ${ }^{\wedge} \mathrm{P}<0.05,{ }^{\Delta} \mathrm{P}<0.01$.

in Table VII showed up-regulation in transition from normal to OLK, and then OLK to OSCC tissue successively. The expression level of the nine genes showed either a positive or a negative relationship with the tissues' degree of carcinogenesis, where their expression levels either decreased or increased consecutively when in transition between normal and OLK tissues, and then again in transition between OLK and OSCC tissues. This is illustrated in Fig. 3 and Table VII. The results from the RT-PCR and genechip were in concordance with each other.

Further validation of the signature genes by real-time PCR. Real-time PCR is universally accepted as one of the most accurate quantitative methods. We randomly chose the GDF-15, XRCC-1, and SOCS-3 genes to further validate the signature genes. The reaction efficiency of the three genes 

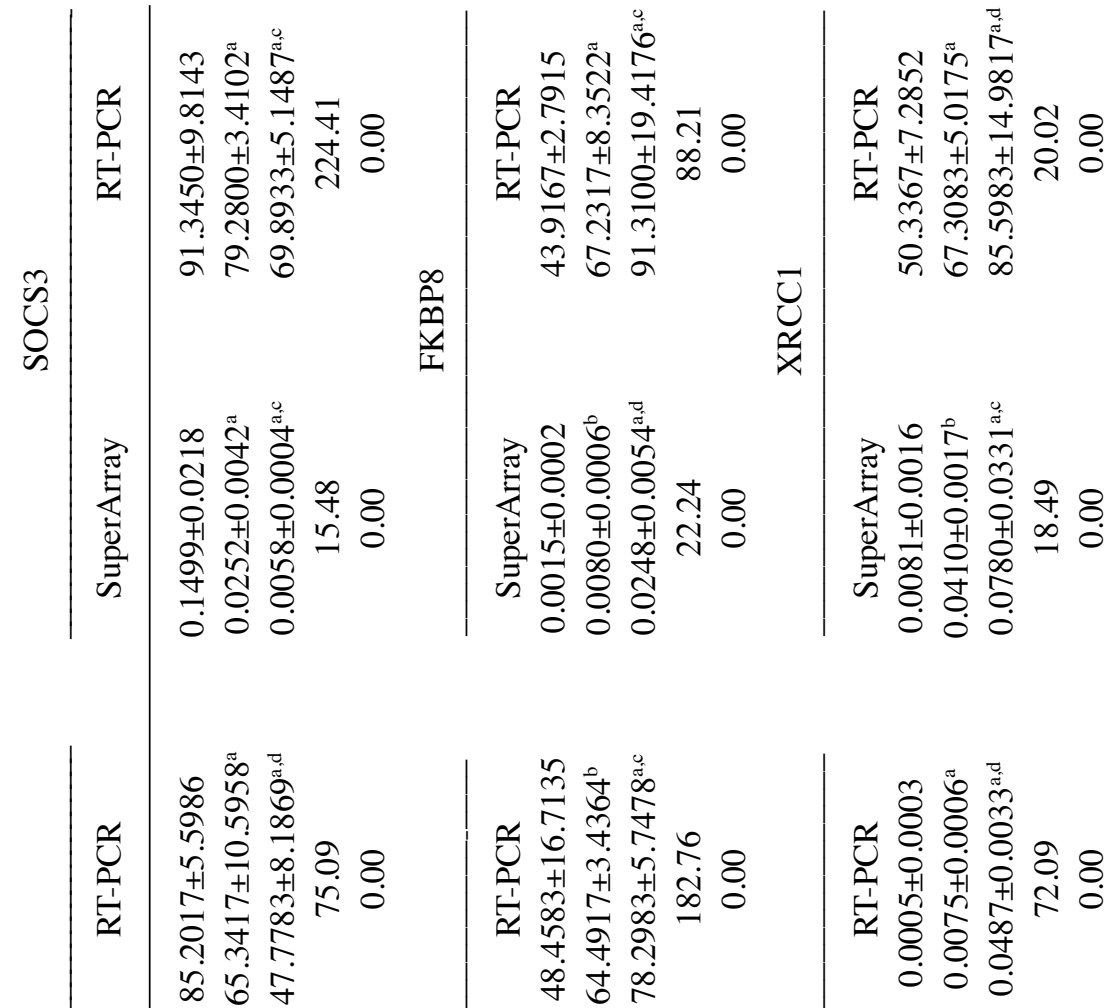

둉ㅎㅇ

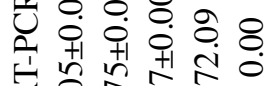

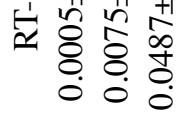

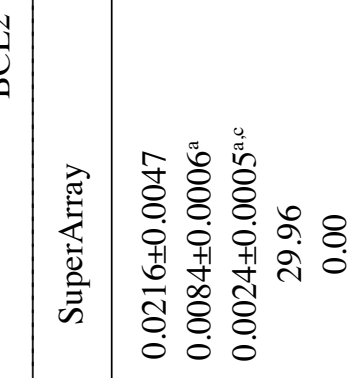

品

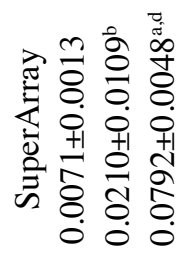

$\overline{\mathrm{Z}}$
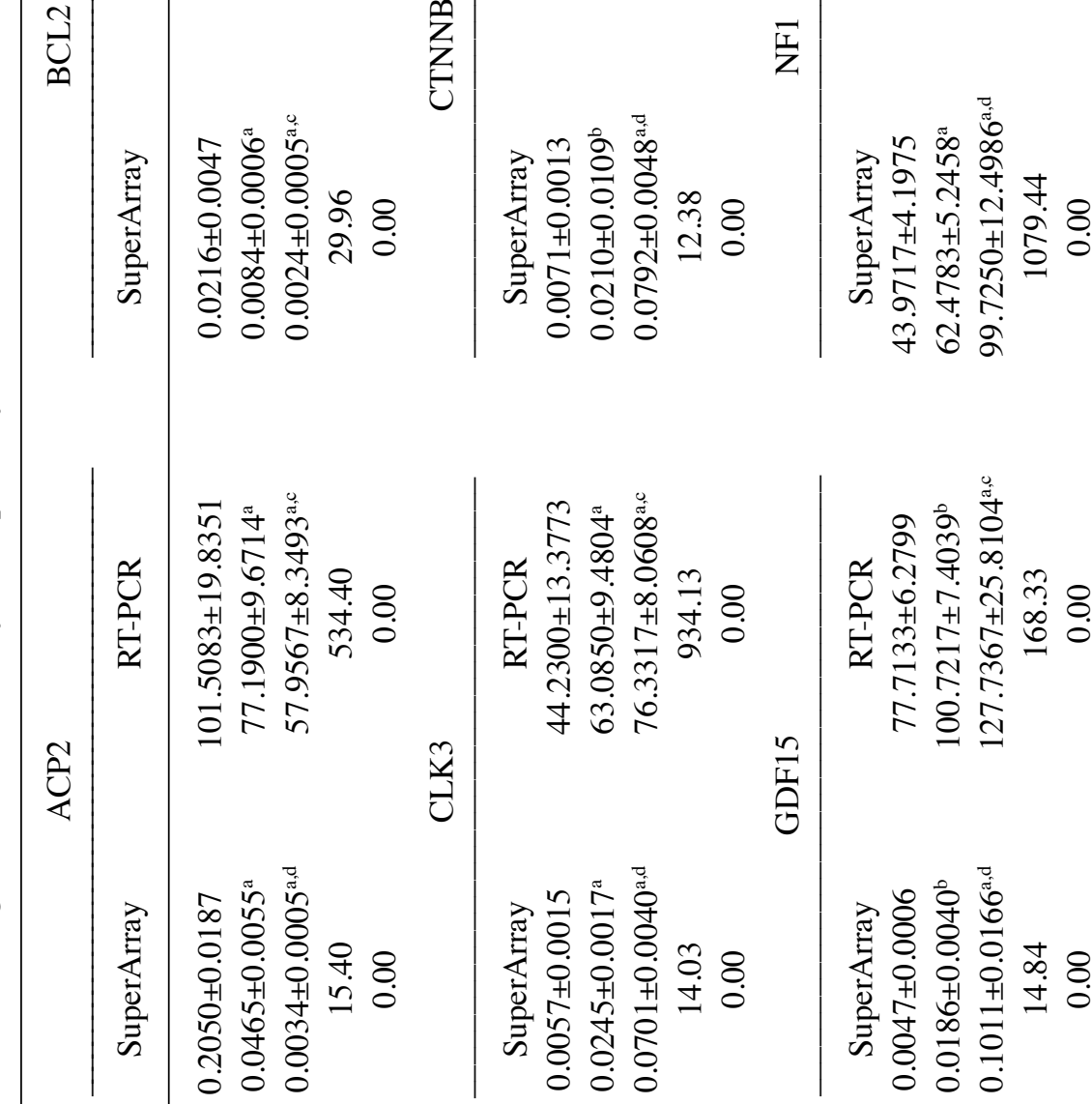

光

寸 ชิำ

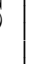

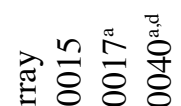

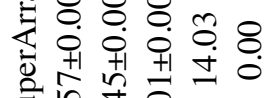

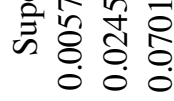

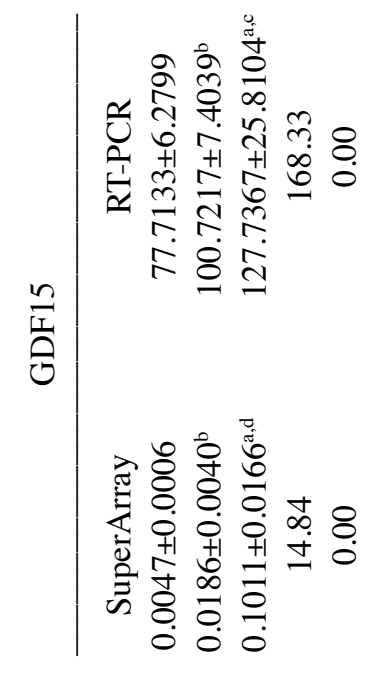

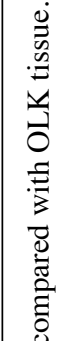

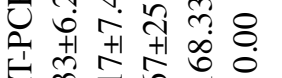
죵

은
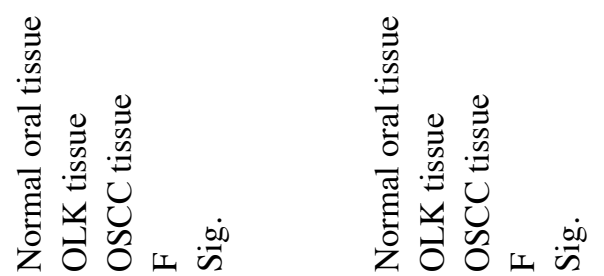


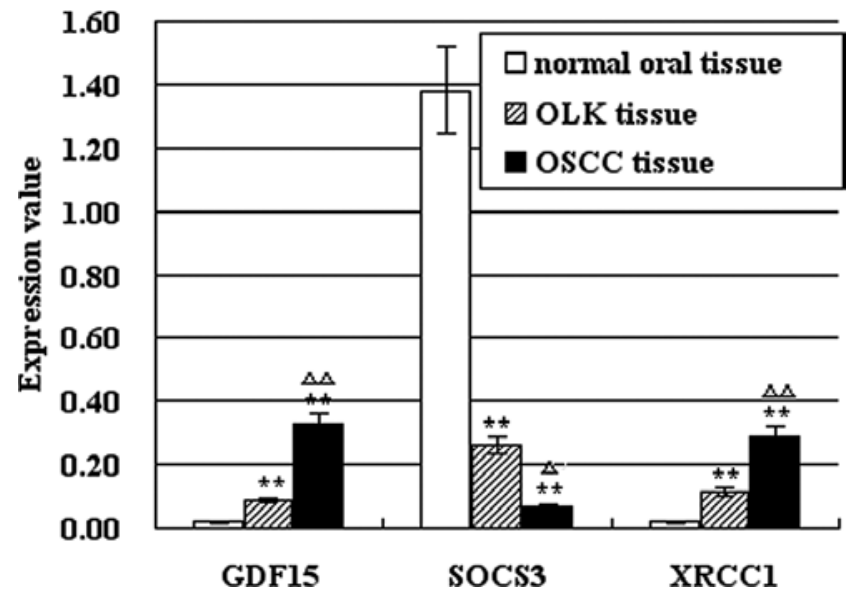

Figure 4. The expression of GDF-15, XRCC-1, SOCS-3 in normal oral, OLK, and OSCC tissue (by real-time PCR). As illustrated above, the real-time PCR results concurred with those obtained from the genechip, showing a similar trend. This validates our results. Compared with normal tissue ${ }^{*} \mathrm{P}<0.05,{ }^{* *} \mathrm{P}<0.01$; compared with OLK tissue ${ }^{\triangle} \mathrm{P}<0.05,{ }^{\triangle} \mathrm{P}<0.01$.

were $>0.9$ (original data not shown). The results (Fig. 4) show that the expression value of the three genes showing a similar trend with those obtained from the genechip. The results are consist with the microarray result. This validates our results.

\section{Discussion}

In the present study, we identified a panel of candidate biomarkers that are predictive of carcinogenesis in OLK. The objective of this program is to detect tumors at an early enough stage that treatment is likely to be successful.

The disappointing survival rate for oral cancer may most probably be attributed to diagnostic delay (20). Microscopic and imaging techniques for cancer screening is often too late for successful intervention $(21,22)$. These techniques are typically used for confirmation. Since most oral cancers arise as asymptomatic small lesions at an early stage, the patients notice them far later when they become symptomatic (23). If we can make use of biomarkers to detect oral cancer at their early stage it will be a promising way to help patients and lower the mortality.

Studies have reported that several single genes play an important role in the carcinogenesis of OLK, such as p53 (24), Ki-67 (25), tumor amplified and overexpressed sequence 1 (TAOS1) (26), major histocompatibility complex class I-related chain A (MICA) (27), Ras association domain family (RASSF) (28), ataxia telangiectasia mutated (ATM) (29), Melanoma-associated antigens-A1-A6 (MAGE-A1-A6) and Melanoma-associated antigen-A12 (MAGE-A12) (30), urinary-type plasminogen activator and uPA receptor (UPA-uPAR) (31), Cytokeratin 17 (Ck17) (32), glucose-regulated protein 94 kDa (Grp94) (33) and so on. In the precancerous oral lesions, survivin (34), MMP-1 and MMP-9 (35) were found to be up-regulated compared with normal oral tissue, while RAR- $\beta 2$ (36), Kail (37) and FHI (38) were inhibited. Our data partly agree with their assessment, however, to date, no single gene has been reported to be a sufficient diagnostic marker in OSCC.
Previous studies have shown that human DNA biomarkers can be identified in saliva as a means to detect oral cancer $(39,40)$. Ziober et al used a supervised learning algorithm, and generated a 25-gene signature for OSCC that can classify normal and OSCC specimens. This 25-gene molecular predictor was $96 \%$ accurate on cross-validation, averaging $87 \%$ accuracy using three independent validation test sets and failing to predict non-oral tumors. Their study showed that DNA microarray gene expression profiling of matched tumor and normal specimens can identify distinct anatomic site expression patterns and a highly significant gene signature distinguishing normal from oral squamous cell carcinoma (OSCC) tissue (41).

However, the cellular sources of the human salivary RNA detected is an important question to be addressed. For oral cancer patients, the detected cancer-associated RNA signature is likely to originate from the matched tumor and/or a systemic response (local or distal) (42). So, whether the saliva is a good source for oral cancer detection needs to be further discussed. In our study, we used tissues as experimental samples for more reliable biomarker detection.

Recent independent studies (43-47) carried out by several research groups indicate that OSCC cells have a unique gene transcription profile, which differs from that of normal cells. Various literature strongly supports the notion that microarray analysis of human cancers far exceeds conventional histopathologic diagnostic systems $(43,48-52)$. For instance, Kuribayashi et al attempted to identify a new genetic diagnosis system for oral epithelial dysplasia. An oligonucleotide microarray was used to analyze expression patterns of 29,952 genes in 10 LP patients. The gene expression patterns between the mild dysplasia and severe dysplasia cases were compared. Of the 96 candidate genes identified to be up-regulated in oral dysplasia, the 16 with the highest differential expression were selected (19).

Also, to identify biomarkers for the early detection of invasive OSCC, Chen et al compared the gene expressions of incident primary OSCC, oral dysplasia, and controls, using Affymetrix U133 2.0 Plus arrays. One hundred and thirty-one differentially expressed probe sets were identified using a training set of 119 OSCC patients and 35 controls. With forward and stepwise logistic regression analyses 10 successive combinations of genes whose expression differentiated OSCC from controls were identified. Two models were found, the first included LAMC2 and COL4A1 and the second, COL1A1 and PADI1 (53).

Interestingly, none of these studies have tested the gene profiles that are successively up- or down-regulated in transition from both normal oral tissues to OLK and then also from OLK to OSCC. For example, certain genes may be up-regulated several-fold in transition between normal and OLK tissue, and then perhaps further up-regula ted on transition from OLK to OSCC tissue. These patterns might form an important basis for OLK carcinogenesis.

As for the genechip we used, it contained probes representing only 440 human cancer-related genes. While the quantity of probes in the array was rather modest, it facilitated in decreasing the background noise that too many genes would have created, and helped us concentrate on cancerrelated genes. 
To date, more than thirty studies incorporating microarray analysis have reported on the genetic changes associated with OSCC.

Choi et al attempted to validate the DNA microarray results on 6 potential biomarkers of OSCC (CDH11, MMP3, SPARC, POSTN, TNC and TGM3) that could serve as biomarkers of OSCC by examining their expression with an alternate quantitative real-time PCR method and by assessing their protein levels by immunohistochemical analysis of tissue microarray sections. Differential expression of CDH11, SPARC, POSTN, TNC and TGM3 were validated (54).

Odani et al analyzed the expression profiles of 8,800 genes in human oral leukoplakia $(n=4)$ and OSCC $(n=2)$ using the Affymetrix GeneChip system and their results were confirmed with RT-PCR. Eight genes were up-regulated $(>2.0$-fold) and 10 were down-regulated $(<0.5$-fold $)$ in all leukoplakias analyzed with the GeneChip. In particular, loricrin and keratins displayed greater differences between normal tissue and leukoplakia. Some of the 18 alternatively expressed genes were markedly down-regulated in squamous cell carcinoma compared with leukoplakia. They suggested that gene abnormalities in cytoskeleton network components might be responsible for the development and progression of oral leukoplakia (17).

Unfortunately, many of these studies have used varying gene expression arrays and platforms, so it is difficult to make a direct comparison with one another $(43,52)$. Using a significant statistical approach, we identified 206 genes differentially expressed between normal oral tissue and OLK $(\mathrm{p}<0.01)$, 143 genes differentially expressed between OLK and OSCC $(p<0.01), 147$ genes differentially expressed between normal oral tissue and $\operatorname{OSCC}(\mathrm{p}<0.01)$. In all of these genes, there were 9 genes successively up- or down-regulated from normal oral tissue to OLK and then to OSCC. Furthermore, the strong correlation of RT-PCR with the array data for gene expression and the validation using real-time PCR strongly indicates that the 9 genes in this list are characteristically expressed genes in the process of OLK carcinogenesis. However, we do understand that the results presented in this study have their limitations. First, the overall sample size is somewhat small. Thus, we did not take gender, age and other factors into consideration. Second, we did not assess the significance of biomarkers at the protein level. Because of these concerns and the recommendations of the Early Detection Research Network (EDRN) of the National Cancer Institute (55), the next step is to validate our results in an independent cohort with a large sample size. Efforts are underway to validate the candidate markers at the protein level and their network function in signal transduction. There is also a need for additional exploratory research into developing a mathematical model to generate a higher power for OSCC discrimination and prediction.

\section{Acknowledgements}

Many thanks to Xin-rong Nan and Xu-bin Yin, the staff of Oral and Maxillofacial Surgery in First Hospital Affiliated to Shanxi Medical University for their invaluable assistance in conducting this research. My sincere gratitude goes to Vikram Shee for his editing support of this study. Finally, special thanks go to the patients who enrolled in this study, it would not have been possible without them.

\section{References}

1. Jemal A, Siegel R, Xu J and Ward E: Cancer statistics, 2010. CA Cancer J Clin 60: 277-300, 2010.

2. The Oral Cancer Foundation [http://www.oralcancerfoundation. org/facts/].

3. Myers JN, Elkins T, Roberts D and Byers RM: Squamous cell carcinoma of the tongue in young adults: increasing incidence and factors that predict treatment outcomes. Otolaryngol Head Neck Surg 122: 44-51, 2000.

4. Pitman KT, Johnson JT, Wagner RL and Myers EN: Cancer of the tongue in patients less than forty. Head Neck 22: 297-302, 2000.

5. Altekruse SF, Kosary CL, Krapcho M, Neyman N, Aminou R, Waldron W, Ruhl J, Howlader N, Tatalovich Z, Cho H, Mariotto A, Eisner MP, Lewis DR, Cronin K, Chen HS, Feuer EJ, Stinchcomb DG and Edwards BK (eds): SEER Cancer Statistics Review, 1975-2007, National Cancer Institute. Bethesda, MD, http://seer.cancer.gov/csr/1975_2007/, based on November 2009 SEER data submission, posted to the SEER web site. 2010.

6. Neville BW and Day TA: Oral cancer and precancerous lesions. CA Cancer J Clin 52: 195-215, 2002

7. Gonsalves WC, Chi AC and Neville BW: Common oral lesions: Part II. Masses and neoplasia. Am Fam Physician 75: 509-512, 2007.

8. Okamoto M, Nishimine M, Kishi M, et al: Prediction of delayed neck metastasis in patients with stage I/II squamous cell carcinoma of the tongue. J Oral Pathol Med 31: 227-233, 2002.

9. Massano J, Regateiro FS, Januario G and Ferreira A: Oral squamous cell carcinoma: review of prognostic and predictive factors. Oral Surg Oral Med Oral Pathol Oral Radiol Endod 102: 67-76, 2006.

10. Ensley JF GJ, Jacobs JR and Lippman SM: Head and neck cancer: emerging perspectives. Academic Press, New York, 2003.

11. Kramer IR, Lucas RB, Pindborg JJ and Sobin LH: Definition of leukoplakia and related lesions: an aid to studies on oral precancer. Oral Surg Oral Med Oral Pathol 46: 518-539, 1978.

12. Liu YM, Huang JH, Feng DY and Guo XC: [Expression of survivin and its correlation to angiogenesis in oral squamous cell carcinoma]. Ai Zheng 24: 1354-1357, 2005

13. Greenman J, Homer JJ and Stafford ND: Markers in cancer of the larynx and pharynx. Clin Otolaryngol Allied Sci 25: 9-18, 2000.

14. Vielba R, Bilbao J, Ispizua A, et al: p53 and cyclin D1 as prognostic factors in squamous cell carcinoma of the larynx. Laryngoscope 113: 167-172, 2003.

15. Chattopadhyay A, Ray JG and Caplan DJ: AgNOR count as objective marker for dysplastic features in oral leukoplakia. J Oral Pathol Med 31: 512-517, 2002.

16. Liu SC and Klein-Szanto AJ: Markers of proliferation in normal and leukoplakic oral epithelia. Oral Oncol 36: 145-151, 2000.

17. Odani T, Ito D, Li MH, et al: Gene expression profiles of oral leukoplakia and carcinoma: genome-wide comparison analysis using oligonucleotide microarray technology. Int J Oncol 28: 619-624, 2006

18. Kondoh N, Ohkura S, Arai M, et al: Gene expression signatures that can discriminate oral leukoplakia subtypes and squamous cell carcinoma. Oral Oncol 43: 455-462, 2007.

19. Kuribayashi Y, Morita K, Tomioka H, Uekusa M, Ito D and Omura K: Gene expression analysis by oligonucleotide microarray in oral leukoplakia. J Oral Pathol Med 38: 356-361, 2009.

20. Wildt J, Bundgaard T and Bentzen SM: Delay in the diagnosis of oral squamous cell carcinoma. Clin Otolaryngol Allied Sci 20: 21-25, 1995.

21. Fong KM SS, Gopal-Srivastava R and Kramer BS: Molecular genetic basis for early cancer detection and cancer susceptibility. In: Molecular Pathology of Early Cancer. Srivastava SHD and Gazdar AF (eds). IOS Press, Amsterdam, The Netherlands, pp13-26, 1998. 
22. Myers LL and Wax MK: Positron emission tomography in the evaluation of the negative neck in patients with oral cavity cancer. J Otolaryngol 27: 342-347, 1998.

23. Epstein JB, Zhang L and Rosin M: Advances in the diagnosis of oral premalignant and malignant lesions. J Can Dent Assoc 68: 617-621, 2002.

24. Lin YC, Huang HI, Wang LH, et al: Polymorphisms of COX-2 $-765 \mathrm{G}>\mathrm{C}$ and $\mathrm{p} 53$ codon 72 and risks of oral squamous cell carcinoma in a Taiwan population. Oral Oncol 44: 798-804, 2008.

25. Teresa DB, Neves KA, Neto CB, et al: Computer-assisted analysis of cell proliferation markers in oral lesions. Acta Histochem 109: 377-387, 2007.

26. Xia J, Chen Q, Li B and Zeng X: Amplifications of TAOS1 and EMS1 genes in oral carcinogenesis: association with clinicopathological features. Oral Oncol 43: 508-514, 2007.

27. Tamaki S, Sanefuzi N, Kawakami M, et al: Association between soluble MICA levels and disease stage IV oral squamous cell carcinoma in Japanese patients. Hum Immunol 69: 88-93, 2008.

28. Imai T, Toyota M, Suzuki H, et al: Epigenetic inactivation of RASSF2 in oral squamous cell carcinoma. Cancer Sci 99: 958-966, 2008.

29. He Y, Chen Q and Li B: ATM in oral carcinogenesis: association with clinicopathological features. J Cancer Res Clin Oncol 134: 1013-1020, 2008.

30. Ries J, Vairaktaris E, Mollaoglu N, Wiltfang J, Neukam FW and Nkenke E: Expression of melanoma-associated antigens in oral squamous cell carcinoma. J Oral Pathol Med 37: 88-93, 2008.

31. Shi $\mathrm{Z}$ and Stack MS: Urinary-type plasminogen activator (uPA) and its receptor (UPAR) in squamous cell carcinoma of the oral cavity. Biochem J 407: 153-159, 2007.

32. Toyoshima T, Vairaktaris E, Nkenke E, Schlegel KA, Neukam FW and Ries J: Cytokeratin 17 mRNA expression has potential for diagnostic marker of oral squamous cell carcinoma. J Cancer Res Clin Oncol 134: 515-521, 2008.

33. Nomura H, Uzawa K, Yamano Y, et al: Network-based analysis of calcium-binding protein genes identifies Grp94 as a target in human oral carcinogenesis. Br J Cancer 97: 792-801, 2007.

34. Tanaka C, Uzawa K, Shibahara T, Yokoe H, Noma H and Tanzawa H: Expression of an inhibitor of apoptosis, survivin, in oral carcinogenesis. J Dent Res 82: 607-611, 2003.

35. Jordan RC, Macabeo-Ong M, Shiboski CH, et al: Overexpression of matrix metalloproteinase-1 and -9 mRNA is associated with progression of oral dysplasia to cancer. Clin Cancer Res 10: 6460-6465, 2004.

36. Youssef EM, Lotan D, Issa JP, et al: Hypermethylation of the retinoic acid receptor-beta(2) gene in head and neck carcinogenesis. Clin Cancer Res 10: 1733-1742, 2004.

37. Uzawa K, Ono K, Suzuki H, et al: High prevalence of decreased expression of KAI1 metastasis suppressor in human oral carcinogenesis. Clin Cancer Res 8: 828-835, 2002.

38. O'Flatharta C, Leader M, Kay E, et al: Telomerase activity detected in oral lichen planus by RNA in situ hybridisation: not a marker for malignant transformation. J Clin Pathol 55: 602-607, 2002 .
39. El-Naggar AK, Mao L, Staerkel G, et al: Genetic heterogeneity in saliva from patients with oral squamous carcinomas: implications in molecular diagnosis and screening. J Mol Diagn 3: 164-170, 2001.

40. Liao PH, Chang YC, Huang MF, Tai KW and Chou MY: Mutation of p53 gene codon 63 in saliva as a molecular marker for oral squamous cell carcinomas. Oral Oncol 36: 272-276, 2000.

41. Ziober AF, Patel KR, Alawi F, et al: Identification of a gene signature for rapid screening of oral squamous cell carcinoma. Clin Cancer Res 12: 5960-5971, 2006.

42. Li Y, St John MA, Zhou X, et al: Salivary transcriptome diagnostics for oral cancer detection. Clin Cancer Res 10: 8442-8450, 2004.

43. Belbin TJ, Singh B, Smith RV, et al: Molecular profiling of tumor progression in head and neck cancer. Arch Otolaryngol Head Neck Surg 131: 10-18, 2005.

44. Tusher VG, Tibshirani R and Chu G: Significance analysis of microarrays applied to the ionizing radiation response. Proc Natl Acad Sci USA 98: 5116-5121, 2001.

45. Eisen MB, Spellman PT, Brown PO and Botstein D: Cluster analysis and display of genome-wide expression patterns. Proc Natl Acad Sci USA 95: 14863-14868, 1998.

46. Livak KJ and Schmittgen TD: Analysis of relative gene expression data using real-time quantitative PCR and the 2(-Delta Delta C(T)) method. Methods 25: 402-408, 2001.

47. Takahashi M, Rhodes DR, Furge KA, et al: Gene expression profiling of clear cell renal cell carcinoma: gene identification and prognostic classification. Proc Natl Acad Sci USA 98: 9754-9759, 2001.

48. Golub TR, Slonim DK, Tamayo P, et al: Molecular classification of cancer: class discovery and class prediction by gene expression monitoring. Science 286: 531-537, 1999.

49. Singh D, Febbo PG, Ross K, et al: Gene expression correlates of clinical prostate cancer behavior. Cancer Cell 1: 203-209, 2002.

50. O'Donnell RK, Kupferman M, Wei SJ, et al: Gene expression signature predicts lymphatic metastasis in squamous cell carcinoma of the oral cavity. Oncogene 24: 1244-1251, 2005.

51. Ginos MA, Page GP, Michalowicz BS, et al: Identification of a gene expression signature associated with recurrent disease in squamous cell carcinoma of the head and neck. Cancer Res 64: $55-63,2004$

52. Somoza-Martin JM, Garcia-Garcia A, Barros-Angueira F, et al: Gene expression profile in oral squamous cell carcinoma: a pilot study. J Oral Maxillofac Surg 63: 786-792, 2005.

53. Chen C, Mendez E, Houck J, et al: Gene expression profiling identifies genes predictive of oral squamous cell carcinoma. Cancer Epidemiol Biomarkers Prev 17: 2152-2162, 2008.

54. Choi P, Jordan CD, Mendez E, et al: Examination of oral cancer biomarkers by tissue microarray analysis. Arch Otolaryngol Head Neck Surg 134: 539-546, 2008.

55. Pepe MS, Etzioni R, Feng Z, et al: Phases of biomarker development for early detection of cancer. J Natl Cancer Inst 93: 1054-1061, 2001 